\title{
PERLINDUNGAN HUKUM TERHADAP KONSUMEN ATAS PENJUALAN KOSMETIK BERBAHAYA DI INDONESIA: SUATU PENDEKATAN KEPUSTAKAAN
}

\author{
Novel Dominika1)', Hasyim2) \\ ${ }^{1)}$ Ekonomi, Universitas Negeri Medan \\ Email: novelsidabutar6@gmail.com \\ ${ }^{2)}$ Ekonomi, Universitas Negeri Medan \\ Email: Mashasyim@gmail.com
}

\begin{abstract}
Seiring dengan berkembangnya ilmu pengetahuan dan teknologi maka kebutuhan hidup manusia kian berkembang pula. Tidak hanya kebutuhan akan sandang, pangan, papan, pendidikan dan kesehatan saja. Kebutuhan akan mempercantik diri pun kian menjadi prioritas utama dalam menunjang penampilan sehari-hari. Perlindungan hukum bagi konsumen kosmetik menurut Undang-Undang No 8 Tahun 1999 tentang Perlindungan Konsumen pasal 45 ayat 1 menyatakan "setiap konsumen yang dirugikan dapat menggugat pelaku usaha melalui lembaga yang bertugas menyelesaikan sengketa antara konsumen dan pelaku usaha atau melalui peradilan yang berada dilingkungan peradilan umum." Upaya pelaku usaha mewujudkan perlindungan hukum bagi konsumen dengan cara memproduksi kosmetik sesuai dengan persyaratan yang ditetapkan Undang-Undang dengan memperhatikan mutu kosmetik, sarana produksi dan distribusi serta kondisi produk yang beredar di pasaran.
\end{abstract}

Kata Kunci : Perlindungan Hukum, Konsumen, Kosmetik Berbahaya 


\section{PENDAHULUAN}

Pada dasarnya manusia diciptakan Tuhan dalam rupa dan wujud yang sempurna. Keinginan manusia untuk tampil lebih cantik dan sempurna khususnya kaum wanita juga merupakan satu hal yang wajar. Selain itu, kehidupan modern, masyarakat saat ini tidak hanya menuntut kemajuan yang berkembang pesat tetapi juga nilai-nilai kecantikan dan keindahan terhadap penampilan. Untuk mencapai tujuan tersebut para wanita rela menghabiskan uangnya untuk membeli perlengkapan kosmetik dengan tujuan memoles wajahnya agar terlihat cantik.

Seiring era perdagangan bebas sekarang ini berbagai jenis kosmetik beredar di pasaran dengan berbagai kegunaan dari berbagai merk juga. Produk kosmetik yang merupakan hasil dari perkembangan industri obat-obatan saat ini sudah berkembang menjadi salah satu kebutuhan pokok masyarakat seiring dengan perkembangan gaya hidup masyarakat. Para pelaku usaha berlomba-lomba menghasilkan berbagai macam produk kecantikan dengan berbagai macam kegunaan bagi masyarakat untuk menarik konsumen sebanyak-banyaknya.

Keinginan manusia terutama wanita untuk selalu tampil cantik, sempurna dalam segala hal kesempatan dimanfaatkan oleh sekelompok pelaku usaha yang tidak bertanggung jawab dengan memproduksi ataupun memperdagangkan kosmetik yang tidak memenuhi persyaratan kepada masyarakat. Sasaran utamanya adalah para kaum wanita yang ingin mendapatkan hasil yang cepat dan maksimal. Mereka akan mudah sekali tertarik untuk membeli produk kosmetik dengan harga yang murah dan cepat terlihat hasilnya. Hal ini yang membuat mereka mencari jalan alternatif dengan.

Hal tersebut juga dipengaruhi oleh berbagai macam obat-obatan atau kosmetik yang digunakan. Kosmetik merupakan salah satu bentuk kebutuhan sekunder dalam kehidupan masyarakat. Berdasarkan Pasal 1 angka 1 Peraturan Menteri Kesehatan Republik Indonesia Nomor 1176/MenKes/PER/VIII/2010 tentang Notifikasi Kosmetika, yang dimaksud dengan "kosmetik adalah bahan atau sediaan yang dimaksudkan untuk digunakan pada bagian luar tubuh manusia (epidermis, rambut ,kuku, bibir dan organ genital bagian luar) atau gigi dan mukosa mulut terutama untuk membersihkan, mewangikan, mengubah penampilan dan/atau memperbaiki bau badan atau melindungi atau memelihara tubuh pada kondisi baik". Dewasa ini bukan hanya kosmetik aman yang beredar di Kota Malang namun juga kosmetik-kosmetik yang berbahaya. Kondisi semacam ini juga dialami di beberapa kota besar di Indonesia.

Kosmetik berbahaya merupakan kosmetik yang mengandung bahan-bahan kimia berbahaya yang dapat menimbulkan efek samping atau gangguan kesehatan bagi penggunanya. Kurangnya pemahaman masyarakat mengenai bahan-bahan yang terkandung di dalam kosmetik dan kurangnya pemahaman masyarakat dalam hal membedakan mana yang kosmetik berbahaya dan mana yang bukan. Konsumen adalah setiap orang pemakai barang dan/atau jasa yang tersedia dalam masyarakat, baik bagi kepentingan diri sendiri, keluarga, orang lain, maupun makhluk hidup lain dan tidak untuk diperdagangkan (pasal 1 angka 2 UU No. 8 Tahun 1999).

Di dalam Undang-Undang Nomor 8 Tahun 1999 tentang Perlindungan Konsumen (UUPK) mengatur mengenai hak konsumen pada pasal 4 yang menyatakan bahwa :

a) Hak atas kenyamanan, keamanan, dan keselamatan dalam mengkonsumsi barang dan/atau jasa.

b) Hak untuk memilih barang dan/atau jasa serta mendapatkan barang dan/atau jasa tersebut sesuai dengan nilai tukar dan kondisi serta jaminan yang dijanjikan.

c) Hak atas informasi yang benar, jelas dan jujur mengenai kondisi dan jaminan barang dan/atau jasa.

d) Hak untuk didengar keluhannya atas barang dan/atau jasa yang digunakan.

e) Hak untuk mendapatkan advokasi, perlindungan dan upaya penyelesaian sengketa perlindungan konsumen secara patut.

f) Hak untuk mendapatkan pembinaan dan pendidikan konsumen.

g) Hak untuk diperlakukan atau dilayani secara benar dan jujur serta tidak diskriminatif.

h) Hak untuk mendapatkan kompensasi ganti rugi dan/atau penggantian, apabila barang dan/atau jasa yang diterima tidak sesuai dengan perjanjian atau tidak sebagaimana mestinya.

i) Hak-hak yang diatur dalam ketentuan perundang-undangan lainnya (pasal 4 
NIAGAWAN Vol 8 No 1 Maret 2019

UU No. 8 Tahun 1999 tentang Perlindungan Konsumen).

Berdasarkan sembilan butir hak konsumen yang diberikan di atas, terlihat bahwa masalah kenyamanan, keamanan, dan keselamatan konsumen merupakan hal yang paling pokok dan utama dalam perlindungan konsumen. Sebaliknya, pelaku usaha bertanggung jawab memenuhi kewajibannya dengan memberikan informasi yang benar, jelas dan jujur mengenai kondisi jaminan barang dan/atau jasa tersebut.

Pelaku usaha adalah setiap orang/perorangan atau badan usaha baik yang bentuk badan hukum maupun bukan, yang didirikan dan berkedudukan atau melakukan kegiatan dalam wilayah hukum negara Republik Indonesia baik sendiri maupun bersama-sama melalui perjanjian menyelenggarakan kegiatan usaha dalam berbagai bidang ekonomi (pasal 1 poin 3 UU No 8 Tahun 1999).

Menurut Pasal 7 UUPK butir (b) disebutkan bahwa dalam suatu transaksi jualbeli, tidak boleh ada unsur penipuan. Pelaku usaha harus menyebutkan dampak negatif dari barang yang dijual, sehingga informasi yang diberikan pelaku usaha kepada konsumen jelas dan menjadi tolak ukur konsumen untuk membelinya.

Label atau barang harus memuat informasi pokok tentang produkyang dijual sebagaimana yang ditetapkan dalam peraturan perundang-undangan yang berlaku dan ditempelkan atau dimasukkan di dalam kemasannya. Informasi yang benar dan bertanggung jawab akan memberikan dampak positif pada putusan pilihan konsumen. Informasi yang tidak benar atau menipu, tentunya potensial dapat menimbulkan kerugian pada konsumen.

Dengan demikian, perlu di Lakukan Penelitian terhadap, Perlindungan Hukum Terhadap Konsumen Atas Penjualan Kosmetik Berbahay Di Indonesia " penting untuk dilakukan mengingat Indonesia merupakan negara hukum yang segala sesuatunya diatur di dalam peraturan sehingga hal-hal yang merugikan konsumen diharapkan tidak terjadi nantinya.

\section{TINJAUAN PUSTAKA}

A. Tinjauan Tentang Perlindungan Hukum

Dalam kehidupan berbangsa dan bernegara perlindungan terhadap konsumen dapat dilakukan melalui berbagai bentuk diantaranya perlindungan ekonomi, sosial, politik, dan perlindungan hukum. Bentuk-bentuk perlindungan terhadap konsumen tersebut yang terpenting adalah perlindungan yang diberikan oleh hukum, sebab hukum dapat mengakomodir berbagai kepentingan konsumen, selain itu hukum memiliki daya paksa sehingga bersifat permanen karena sifatnya yang konstitusional yang diakui dan ditaati keberlakuannya dalam kehidupan bermasyarakat.

Perlindungan hukum dapat diartikan perlindungan oleh hukum atau perlindungan dengan menggunakan pranata dan sarana hukum. Ada beberapa cara perlindungan secara hukum, antara lain sebagai berikut :

1. Membuat peraturan (by giving regulation), yang bertujuan untuk :

2. Memberikan hak dan kewajiban;

3. Menjamin hak-hak para subjek hukum

4. Menegakkan peraturan (by the law enforcement) melalui :

a. Hukum administrasi negara yang berfungsi untuk mencegah (preventif) terjadinya pelanggaran hak-hak konsumen dengan perijinan dan pengawasan.

b. Hukum pidana yang berfungsi untuk menanggulangi (repressive) setiap pelanggaran terhadap peraturan perundang-undangan, dengan cara mengenakan sanksi hukumberupa sanksi pidana dan hukuman.

c. Hukum perdata yang berfungsi untuk memulihkan hak (curative recovery) dengan membayar kompensasi atau ganti kerugian.

Sehingga dapat ditarik kesimpulan pengertian perlindungan hukum adalah suatu perlindungan yang diberikan terhadap subyek hukum dalam bentuk perangkat hukum baik yang bersifat preventif maupun yang bersifat reprsif, baik yang tertulis maupun tidak tertulis, dengan kata lain perlindungan hukum sebagai suatu gambaran dari fungsi hukum, yaitu konsep dimana hukum dapat memberikan suatu keadilan, ketertiban, kepastian, kemanfaatan dan kedamaian.

\section{B. Tinjauan Tentang Konsumen}

Menurut Az.Nasution menegaskan beberapa batasan konsumen yaitu :

1) Konsumen adalah setiap orang yang mendapatkan barang atau jasa digunakan untuk tujuan tertentu. 
2) Konsumen antara adalah setiap orang yang mendapatkan barang dan/jasa untuk digunakan dengan tujuan membuat barang/ jasa lain untuk diperdagangkan (tujuan komersial).

3) Konsumen akhir, adalah setiap orang alami yang mendapat dan menggunakan barang dan/atau jasa untuk tujuan memenughi kebutuhan hidupnya pribadi, keluarga dan atau rumah tangga dan tidakuntuk diperdagangkan kembali (non komersial).

Pengertian konsumen menurut Undang-

Undang Nomor 8 Tahun 1999 tentang Perlindungan Konsumen dalam pasal 1 ayat (2) yaitu :

"Konsumen adalah setiap orang pemakai barang dan/atau jasa yang tersedia dalam masyarakat, baik bagi kepentingan diri sendiri, keluarga, orang lain, maupun makhluk hidup lain dan tidak untuk diperdagangkan.”

Adapun asas perlindungan Konsumen antara lain:

1) Asas Manfaat, mengamanatkan bahwa segala upaya dalam penyelenggaraan perlindungan ini harus memberikan manfaat sebesar-besarnya bagi kepentingan konsumen dan pelaku usaha secara keseluruhan.

2) Asas Keadilan, partisipasi seluruh rakyat dapat diwujudkan secara maksimal dan memberikan kesempatan kepada konsumen dan pelaku usaha untuk memperoleh haknya dan melaksanakan kewajibannya secara adil.

3) Asas Keseimbangan, memberikan keseimbangan antara kepentingan konsumen, pelaku usaha, dan pemerintah dalam arti materiil ataupun spiritual.

4) Asas Keamanan dan Keselamatan Konsumen, memberikan jaminan atas keamanan dan keselamatan kepada konsumen dalam penggunaan, pemakaian dan pemanfaatan barang dan/atau jasa yang dikonsumsi atau digunakan.

5) Asas Kepastian Hukum, baik pelaku usaha maupun konsumen mentaati hukum dan memperoleh keadilan dalam penyelenggaraan perlindungan konsumen, serta negara menjamin kepastian hukum.

Telah disebutkan bahwa tujuan dari UndangUndang Nomor 8 Tahun 1999 adalah melindungi kepentingan konsumen yang tercantum dalam pasal 3 yaitu : a) Meningkatkan kesadaran, kemampuan, dan kemandirian konsumen untuk melindungi diri

b) Mengangkat harkat dan martabat konsumen denga cara menghindarkannya dari ekses negatif pemakaian barang dan/atau jasa

c) Meningkatkan pemberdayaan konsumen dalam memilih, menentukan, dan menuntut hak-haknya sebagai konsumen

d) Menciptakan sistem perlindungan konsumen yang mengandung unsur kepastian hukum dan keterbukaan informasi serta akses untuk mendapatkan informasi

e) Menumbuhkan kesadaran pelaku usaha mengenai pentingnya perlindungan konsumen sehingga tumbuh sikap yang jujur dan bertanggung jawab dalam berusaha

f) Meningkatkan kualitas barang dan/atau jasa, kesehatan, kenyamanan, keamanan, dan keselamatan konsumen.

\section{Tinjauan Tentang Kosmetik Berbahaya}

Berdasarkan Pasal 1 angka 1 Peraturan Menteri Kesehatan Republik Indonesia Nomor 1176/MenKes/PER/VIII/2010 tentang Notifikasi Kosmetika, yang dimaksud dengan "kosmetik adalah bahan atau sediaan yang dimaksudkan untuk digunakan pada bagian luar tubuh manusia (epidermis, rambut ,kuku, bibir dan organ genital bagian luar) atau gigi dan mukosa mulut terutama untuk membersihkan, mewangikan, mengubah penampilan dan/atau memperbaiki bau badan atau melindungi atau memelihara tubuh pada kondisi baik".

Dewasa ini bukan hanya kosmetik aman yang beredar di Kota Malang namun juga kosmetik-kosmetik yang berbahaya. Kosmetik berbahaya merupakan kosmetik yang mengandung bahan-bahan kimia berbahaya yang dapat menimbulkan efek samping atau gangguan kesehatan bagi penggunanya. Kurangnya pemahaman masyarakat mengenai bahan-bahan yang terkandung di dalam kosmetik dan kurangnya pemahaman masyarakat dalam hal membedakan mana yang kosmetik berbahaya dan mana yang bukan.

Kosmetika yang beredar di pasaran sekarang ini dibuat dengan berbagai jenis bahan dasar dan cara pengolahannya. Menurut bahan yang digunakan dan cara pengolahannya, kosmetika dapat dibagi menjadi 2 golongan besar yaitu kosmetika tradisional dan kosmetika modern.

Kosmetika yang beredar dipasaran Indonesia ada tiga macam, yaitu kosmetika 
tradisional, kosmetika modern, dan kosmedics cosmetics medicated

a. Kosmetika Tradisional

Kosmetika Tradisional adalah kosmetika alamiah atau kosmetika asli yang dapat dibuat sendiri langsung dari bahan-bahan segar atau yang telah dikeringkan, buah-buahan dan tanamtanaman disekitar kita. Cara tradisional ini merupakan kebiasaan atau tradisi yang diwariskan turun-temurun dari leluhur atau nenek moyang kita .

\section{b. Kosmetika Modern}

Kosmetika Modern adalah kosmetika yang diproduksi secarapabrik (laboratorium), dimana telah dicampur dengan zat-zat kimia untuk mengawetkan kosmetika tersebut agar tahan lama, sehingga tidak cepat rusak .

1) Kosmetik yang diproduksi dan diedarkan harus memenuhi persyaratan sebagai berikut Menggunakan bahan yang memenuhi standart dan persyaratan mutu serta persyaratan lain yang ditetapkan.

2) Diproduksi dengan menggunakan cara pembuatan kosmetik yang baik.

3) Terdaftar pada dan mendapat izin edar dari Badan Pengawas Obat dan Makanan Republik Indonesia (BPOM $\mathrm{RI})$.

\section{METODE PENELITIAN}

Berdasarkan permasalahan yang dihadapi dalam penelitian ini, maka penelitian ini bersifat analitis, yang mana penulisan hukum ini merupakan atau menggambarkan mengenai Perlindungan Hukum Terhadap Konsumen Atas Peredaran Produk Kosmetik Berbahaya Di Indonesia

Penelitian ini bersifat deskriptif, sehingga data yang digunakan adalah data skunder, yaitu data yang diperoleh melalui bahan kepustakaan yang erat hubungannya dengan bahan-bahan hukum primer dan dapat membantu menganalisis dan memahami bahan hukum primer

Dalam penelitian ini, semua data yang terkumpul dalam penelitian ini bersifat sekunder akan dianalisis secara kualitatif. Analisis kualitatif merupakan analisis data yang menggunakan penjelasan berupa kumpulan data/ uraian dengan prosedur teoritis, serta pikiran yang logis. Menurut umar (2000:38) menyebutkan tujuan kualitatif adalah memaparkan atau mendeskripsikan hal-hal yang berhubungan dengan objek penelitian.

\section{HASIL DAN PEMBAHASAN}

Kosmetik merupakan salah satu faktor penting bagi masyarakat modern khususnya perempuan untuk menunjang penampilan dan menambah rasa percaya diri dalam melakukan segala aktifitas sehari-hari. Berbagai cara dilakukan masyarakat guna memperindah serta mempercantik penampilannya. Kebutuhan masyarakat yang tinggi akan produk kosmetik menjadi peluang besar bagi pelaku usaha untuk terus meningkatkan produksi kosmetiknya, hal ini terbukti dengan semakin gencarnya promosi dari pihak produsen melalui berbagai media dengan strategi promosi yang dikembangkan sedemikian rupa sehingga terkadang mengubur sikap rasional konsumen yang pada akhirnya lengah dalam menyeleksi produk-produk yang beredar di pasaran.

Perlindungan hukum bagi konsumen pada dasarnya adalah melindungi hak-hak konsumen. Hak-hak konsumen sebenarnya sudah dirumuskan secara jelas dan terinci di dalam peraturan perundang-undangan yang semestinya diperhatikan dan dilindungi oleh pihak pelaku usaha, hanya dalam prakteknya hal ini sering terabaikan karena iktikad tidak baik dari pelaku usaha serta dalam melakukan usaha hanya didorong untuk mendapatkan keuntungan yang sebesar-besarnya.

A. Persyaratan untuk menjamin mutu, keamanan, dan kemanfaatan kosmetik

Pelaku usaha yang akan mengedarkan kosmetik harus memenuhi persyaratan dasar untuk menjamin mutu, keamanan, dan kemanfaatan dari kosmetik yang akan diproduksi. Persyaratannya antara lain:

1. Industri kosmetik harus memenuhi persyaratan Cara Pembuatan Kosmetik yang Baik .

2. Industri yang memenuhi persyaratan Cara Pembuatan Kosmetik yang Baik diberikan Sertifikat oleh Kepala Badan. (Pasal 8 Peraturan Kepala Badan POM RI Nomor HK.00.05.4.17.45 tentang Kosmetik).

3. Langkah utama untuk menjamin mutu, keamanan, dan kemanfaatan kosmetik bagi pemakainya adalah dengan menerapkan CPKB pada seluruh aspek dan rangkaian produksi. CPKB merupakan salah satu faktor penting untuk dapat menghasilkan produk kosmetik yang memenuhi standar 
mutu dan keamanan. (Peraturan Kepala Badan POM RI Nomor HK.00.05.4.3870 tentang Pedoman Cara Pembuatan Kosmetik Yang Baik).

Perusahaan yang akan memproduksi kosmetik harus mempunyai izin produksi terlebih dahulu sebelum perusahaan melakukan kegiatan pembuatan kosmetik. Prosedur perizinan produksi kosmetik tersebut sebagai berikut:

a) Pembuatan kosmetika hanya dapat dilakukan oleh industri kosmetika. (Pasal 3 Peraturan Menteri Kesehatan Republik Indonesia Nomor 63 Tahun 2013 tentang Izin Produksi Kosmetika).

b) (1) Industri kosmetika yang akan membuat kosmetika harus memiliki izin produksi.

(2) Izin produksi sebagaimana dimaksud pada huruf d angka (1) diberikan oleh Direktur Jenderal. (Pasal 4 Peraturan Menteri Kesehatan Republik Indonesia Nomor 63 Tahun 2013 tentang Izin Produksi Kosmetika).

c) Izin produksi berlaku selama 5 (lima) tahun dan dapat diperpanjang selama memenuhi ketentuan yang berlaku. (Pasal 5 Peraturan Menteri Kesehatan Republik Indonesia Nomor 63 Tahun 2013 tentang Izin Produksi Kosmetika). (1) Izin produksi kosmetika diberikan sesuai bentuk dan jenis sediaan kosmetika yang akan dibuat.

(2) Izin produksi sebagaimana dimaksud pada huruf $f$ angka (1), dibedakan atas 2 (dua) golongan sebagai berikut:

B. Pendaftaran produk kosmetik

Kosmetik yang akan diedarkan harus memiliki izin edar atau nomor pendaftaran agar dapat diawasi oleh Badan Pengawas Obat dan Makanan (BPOM). Peraturan yang berkaitan dengan pendaftaran produk kosmetik yaitu:

Alat kesehatan, kosmetika, dan perbekalan rumah tangga yang diedarkan atau dijual di wilayah Indonesia harus didaftarkan pada Departemen Kesehatan cq.Direktorat Jenderal Pengawas Obat dan Makanan. (Pasal 2 Peraturan Menteri Kesehatan Nomor 140/Menkes/Per/III/1991 tentang Wajib Daftar Alat kesehatan, kosmetika, dan Perbekalan Kesehatan Rumah Tangga).

C. Persyaratan produksi dan peredaran kosmetik

Kosmetik yang diproduksi atau diedarkan harus memenuhi beberapa persyaratan sebagai berikut:
NIAGAWAN Vol 8 No 1 Maret 2019

a. Persyaratan produksi kosmetik

1) Menggunakan bahan yang memenuhi standar dan persyaratan mutu serta persyaratan lain yang ditetapkan.

2) Diproduksi dengan menggunakan cara pembuatan yang baik.

3) Terdaftar pada dan mendapat izin edar dari Badan Pengawas Obat dan Makanan. (Pasal 2 Keputusan Badan POM RI Nomor HK.00.05.4.1745 tentang Kosmetik).

\section{Perlindungan Hukum Bagi Konsumen}

Perlindungan hukum bagi konsumen pada dasarnya adalah melindungi hak-hak konsumen. Hak-hak konsumen sebenarnya sudah dirumuskan secara jelas dan terinci di dalam peraturan perundang-undangan yang semestinya diperhatikan dan dilindungi oleh pihak pelaku usaha, hanya dalam prakteknya hal ini sering terabaikan karena iktikad tidak baik dari pelaku usaha serta dalam melakukan usaha hanya didorong untuk mendapatkan keuntungan yang sebesar-besarnya.

E. Tujuan Perlindungan Konsumen

Pasal 3 Undang-Undang Nomor 8 Tahun 1999 tentang Perlindungan Konsumen, menyebutkan bahwa perlindungan konsumen bertujuan:

1. meningkatkan kesadaran, kemampuan dan kemandirian konsumen untuk melindungi diri;

2. mengangkat harkat dan martabat konsumen dengan cara menghindarkannya dari ekses negatif pemakaian barang dan/atau jasa;

3. meningkatkan pemberdayaan konsumen dalam memilih, menentukan dan menuntut hak-haknya sebagai konsumen;

4. menciptakan sistem perlindungan konsumen yang mengandung unsur kepastian hukum dan keterbukaan informasi serta akses untuk mendapatkan informasi;

5. menumbuhkan kesadaran pelaku usaha mengenai pentingnya perlindungan konsumen sehingga tumbuh sikap yang jujur dan bertanggung jawab dalam berusaha;

6. meningkatkan kualitas barang dan/atau jasa yang menjamin kelangsungan usaha produksi barang dan/atau jasa, kesehatan, kenyamanan, keamanan, dan keselamatan konsumen.

Sehubungan dengan hal tersebut, menurut Ahmadi Miru dan Sutarman Yodo dalam 
NIAGAWAN Vol 8 No 1 Maret 2019

bukunya Hukum Perlindungan Konsumen, menyatakan bahwa:

Pasal 3 Undang-Undang Perlindungan Konsumen ini, merupakan isi pembangunan nasional sebagaimana disebutkan dalam Pasal 2 sebelumnya, karena tujuan perlindungan konsumen yang ada itu merupakan sasaran akhir yang harus dicapai dalam pelaksanaan pembangunan di bidang hukum perlindungan konsumen

F. Perlindungan hukum bagi konsumen terhadap peredaran kosmetik yang mengandung bahan berbahaya

Kasus tersebut perlindungan hukumnya dapat menuntut ganti kerugian tetapi dalam hal ganti rugi tersebut bukan merupakan tugas pokok dari BPOM, karena BPOM hanya melakukan pengawasan. Apabila penyegelan terhadap sarana, BPOM tidak mempunyai kewenangan tetapi hanya melakukan pengawasan terhadap produk, yang mempunyai kewenangan adalah Dinas. Perindustrian dan Perdagangan. Undang-Undang Perlindungan Konsumen untuk penyelesaian sengketa konsumen ada lembaga tersendiri untuk menyelesaikan sengketa tersebut.

\section{KESIMPULAN DAN SARAN Kesimpulan}

Kosmetik merupakan salah satu faktor penting bagi masyarakat modern khususnya perempuan untuk menunjang penampilan dan menambah rasa percaya diri dalam melakukan segala aktifitas sehari-hari. Berbagai cara dilakukan masyarakat guna memperindah serta mempercantik penampilannya. Kebutuhan masyarakat yang tinggi akan produk kosmetik menjadi peluang besar bagi pelaku usaha untuk terus meningkatkan produksi kosmetiknya, hal ini terbukti dengan semakin gencarnya promosi dari pihak produsen melalui berbagai media dengan strategi promosi yang dikembangkan sedemikian rupa sehingga terkadang mengubur sikap rasional konsumen yang pada akhirnya lengah dalam menyeleksi produk-produk yang beredar di pasaran.

Perlindungan hukum bagi konsumen pada dasarnya adalah melindungi hak-hak konsumen. Hak-hak konsumen sebenarnya sudah dirumuskan secara jelas dan terinci di dalam peraturan perundang-undangan yang semestinya diperhatikan dan dilindungi oleh pihak pelaku usaha, hanya dalam prakteknya hal ini sering terabaikan karena iktikad tidak baik dari pelaku usaha serta dalam melakukan usaha hanya didorong untuk mendapatkan keuntungan yang sebesar-besarnya.

Perlindungan hukum terhadap konsumen kosmetik agar merasa nyaman, aman, dan selamat berkaitan dengan peredaran kosmetik yang mengandung bahan berbahaya secara normatif sebenarnya sudah diupayakan oleh pemerintah dan jajarannya dengan menetapkan peraturan-peraturan mengenai pembinaan dan pengawasan berdasarkan Keputusan Badan POM RI Nomor HK.03.1.23.12.11.10052 Tahun 2011 tentang Pengawasan Produksi dan Peredaran Kosmetika dan sanksi berdasarkan Undang-Undang Nomor 36 Tahun 2009 tentang Kesehatan yang diharapkan dapat membuat para pelaku usaha sadar sehingga melakukan usaha dengan iktikad baik.

Perlindungan terhadap hak konsumen kosmetik atas informasi yang benar, jelas, dan jujur mengenai kondisi dan jaminan barang dan/atau jasa dalam Peraturan Badan POM RI Nomor HK.00.05.4.17.45 Tentang Kosmetik sebenarnya sudah diatur secara jelas berkaitan dengan kewajiban pelaku usaha untuk memberi informasi yang selengkap-lengkapnya untuk menghindari timbulnya kerugian pada pihak konsumen kosmetik.

\section{REFERENSI}

Miru, Ahmadi, 2011, Prinsip-prinsip Perlindungan Hukum Bagi Konsumen di Indonesia, Jakarta: PT. Raja Grafindo Persada.

http://www.republika.co.id/berita/nasional/umu m/13/05/16/mmvzmy-bpom-sitakosmetik-ilegal-mengandung-obatterlarang

Liwe, Eklesia. 2013. Perlindungan Hukum Bagi Konsumen Terhadap Kosmetika Tanpa Label. Vol 1. No 1. Jurnal Edisi Khusus

Nasution, Az, 2001, Hukum Perlindungan Konsumen Suatu Pengantar, Jakarta: Diadit Media.

Numardjito, 2000, Kesiapan Perangkat Peraturan Perundang-undangan tentang Perlindungan Konsumen di Indonesia, dalam Husni Syawali dan Neni Sri Imaniyati, Penyunting, Hukum 
Perlindungan Konsumen, Mandar Maju, Bandung.

Sidharta, 2000, Hukum Perlindungan Konsumen, Jakarta: Grasindo.

Rumuat, Elfiaene. 2014. Aspek Hukum Perlindungan Konsumen Terhadap Penyebaran Kosmetik Palsu. Vol II. No 6. Jurnal Lex et Societatis

Sidharta, 2004, Hukum Perlindungan Konsumen Indonesia, Jakarta: PT. Grasindo Edisi 